\title{
Endothelial Cell Injury Initiates Glomerular Sclerosis in the Rat Remnant Kidney
}

\author{
Larry K. Lee, * Timothy W. Meyer, ${ }^{\ddagger}$ Allan S. Pollock, ${ }^{\star}$ and David H. Lovett* \\ * Department of Medicine, Division of Nephrology (111J), San Francisco Veterans Administration Medical Center/University of \\ California at San Francisco, San Francisco, California 94121; and ${ }^{\ddagger}$ Stanford University/Palo Alto Verterans Administration Medical \\ Center, Palo Alto, California 94304
}

\begin{abstract}
The development of progressive glomerulosclerosis in the renal ablation model has been ascribed to a number of humoral and hemodynamic events, including the peptide

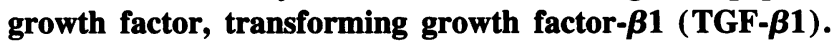
An important role has also been attributed to angiotensin II (AII), which, in addition to its hemodynamic effects, can stimulate transcription of TGF- $\beta 1$. We postulated that increased glomerular production of AII, resulting from enhanced intrinsic angiotensinogen expression, stimulates local TGF- $\beta 1$ synthesis, activating glomerular matrix protein synthesis, and leads to sclerosis. Using in situ reverse transcription, the glomerular cell sites of $\alpha-1$ (IV) collagen, fibronectin, laminin B1, angiotensinogen, and TGF-ß1 mRNA synthesis were determined at sequential periods following renal ablation. The early hypertrophic phase was associated with global, but transient, increases in the mRNA for $\alpha-1$ (IV) collagen. No changes were noted for fibronectin, TGF- $\beta 1$, and angiotensinogen mRNAs. At $24 \mathrm{~d}$ after ablation, at which time sclerosis is not evident, endothelial cells, particularly in the dilated capillaries at the vascular pole, expressed angiotensinogen and TGF- $\beta 1$ mRNAs, as well as fibronectin and laminin B1 RNA transcripts. By $74 \mathrm{~d}$ after ablation angiotensinogen and TGF- $\beta 1$ mRNAs were widely distributed among endothelial and mesangial cells, and were particularly prominent in regions of evolving sclerosis. These same regions were also notable for enhanced expression of matrix protein mRNAs, particularly fibronectin. All receptor blockade inhibited angiotensinogen, TGF- $\beta 1$, fibronectin, and laminin B1 mRNA expression by the endothelium. We conclude that, as a result of hemodynamic changes, injured or activated endothelium synthesizes angiotensinogen, triggering a cascade of TGF- $\beta 1$ and matrix protein gene expression with resultant development of the segmental glomerular sclerotic lesion. (J. Clin. Invest. 1995. 96:953-964.) Key words: extracellular matrix • angiotensinogen $\cdot \mathrm{mRNA} \cdot$ glomerulosclerosis $\bullet$ transforming growth factor- $\beta 1$
\end{abstract}

\section{Introduction}

Glomerular sclerosis is a common feature of many forms of human renal disease and frequently contributes towards a relent-

Address correspondence David H. Lovett, Department of Medicine, Division of Nephrology (111J), San Francisco Veterans Administration Medical Center/University of California at San Francisco, 4150 Clement Street, San Francisco, CA 94121. Phone:415-750-2032; FAX:415-7506949.

Received for publication 16 May 1994 and accepted in revised form I May 1995.

The Journal of Clinical Investigation, Inc

Volume 96, August 1995, 953-964 less and inevitable decline in renal function (1). The sclerotic lesion results from the progressive accumulation of several extracellular matrix (ECM) ${ }^{1}$ proteins (2), and much effort has been directed towards determining the molecular mechanisms underlying this event. Subtotal renal ablation (5/6 nephrectomy) in adult rats has served as a useful and extensively studied animal model of this process. Subtotal ablation elicits a complex glomerular response, initially consisting of a rapid hypertrophic phase, followed by a variable period of relative quiescence, and finally by the development of segmental glomerular sclerosis $(3,4)$. This evolving pattern of injury has been attributed to a number of diverse factors accruing as the result of loss of renal mass, including metabolic, hematologic, and hemodynamic alterations (4-6). The renin-angiotensin system contributes substantially to the development of glomerular sclerosis after $5 / 6$ nephrectomy. Angiotensin II (AII) receptor blockade $(7,8)$ or the inhibition of AII synthesis by converting enzyme inhibitors $(9,10)$ markedly retards disease progression after renal ablation. Preventing the production of AII can also limit the progression of pre-existing glomerular injury (11). Since AII has multiple cellular effects in addition to its role in hemodynamic regulation $(12,13)$, the precise role of this hormone in the development of glomerular sclerosis remains uncertain. Additionally, the initial stimulus and the specific cellular origins of AII within the glomerulus remain to be defined.

Recent studies in other vascular tissues have suggested that some of the pathophysiologic actions of AII result from its stimulation of TGF- $\beta$ expression $(14,15)$. The TGF- $\beta$ s are a multifunctional family of peptides that modulate a wide range of processes, including wound healing, cell growth and differentiation, and is involved in embryogenesis (16). These peptides also have multiple effects on glomerular cell functions, including modulation of the synthesis of ECM proteins and of the secretion of proteinases and proteinase inhibitors (17-23). TGF- $\beta 1$, the most extensively studied form, is particularly important as it mediates the actions of other cytokines and, significantly, can stimulate its own expression (24). The TGF- $\beta$ s, and TGF- $\beta 1$ in particular, have also been implicated in the progression of several models of glomerular disease, including immune complex-mediated glomerulonephritis (25-29), antiglomerular basement membrane disease (30), and diabetic glomerulosclerosis (31). In addition, unilateral nephrectomy in rats has been shown to induce changes in TGF- $\beta 1$ gene expression in remnant glomeruli (32).

The endothelial cell plays a central role in many of the pathophysiologic processes affecting vascular tissues. Vascular endothelial cells secrete multiple vasoactive substances critical in the regulation of vascular tone, as well as a wide array of cytokines and growth factors, such as TGF- $\beta$ (33) and AII

1. Abbreviations used in this paper: AII, angiotensin II; ECM, extracellular matrix; GBM, glomerular basement membrane; ISRT, in situ reverse transcription. 
(34). Furthermore, the endothelial cell appears to be a critical mediator in the progression of vascular disease $(33,35)$, where endothelial cell injury results in local increases in angiotensinogen and, presumably, AII expression $(33,36)$. After renal ablation Kriz and colleagues (37) have noted that endothelial cells in areas destined to develop sclerosis exhibit ultrastructural changes of cellular injury. This suggests that the development of glomerular sclerosis is in some respects similar to the injury pattern in other vascular systems.

AII plays a role in vascular injury and has been clearly implicated as a central mediator in the development of sclerosis in several disease models. We therefore hypothesized that increased local generation of AII, resulting from enhanced local angiotensinogen synthesis, occurs in areas of glomerular microvascular injury. Local AII generation, in turn, stimulates increased TGF- $\beta 1$ synthesis by intrinsic glomerular cells, leading to ECM accumulation and, ultimately, segmental glomerular sclerosis. Using a recently developed in situ reverse transcription technique (ISRT, reference 38), we evaluated the specific cell types and the temporal patterns of expression for several relevant mRNAs within the glomerulus after subtotal renal ablation. The mRNAs studied included angiotensinogen, TGF- $\beta 1$, and three glomerular ECM protein components: fibronectin, $\alpha-1$ (IV) collagen, and laminin B1. The results of these studies suggest that endothelial cells, injured or activated by hemodynamic factors, augment intraglomerular AII generation via increased local angiotensinogen synthesis which then leads to increased TGF- $\beta 1$ synthesis and the development and progression of segmental glomerular sclerosis.

\section{Methods}

Reagents and proteins. Diethylpyrocarbonate (DEPC), BSA, EDTA, sodium chloride, potassium chloride, monovalent and divalent sodium phosphate, sodium citrate, monobasic potassium phosphate, magnesium chloride, Tris base, actinomycin-D, 30\% hydrogen peroxide, diaminobenzidine (DAB), nickel chloride, 3-aminopropyltriethoxysilane, and paraformaldehyde were from Sigma Chemical Co. (St. Louis, MO). Triton X-100 and dithiothreitol (DTT) were from Bio-Rad Laboratories (Richmond, CA). Yeast tRNA, dGTP, dCTP, and dTTP were from Boehringer Mannheim Corp. (Indianapolis, IN). Placental RNase inhibitor (RNasin) was from Promega Corp. (Madison, WI). Biotin-7-dATP was from GIBCO BRL (Gaithersburg, MD). AMV Reverse Transcriptase was from Life Sciences, Inc. (St. Petersburg, FL). Methyl green and Bouin's fixative were from Polysciences, Inc. (Warrington, PA). Normal rabbit serum, normal goat serum, rat whole serum, avidinbiotin peroxidase ( $\mathrm{ABC}$-peroxidase), avidin-biotin alkaline phosphatase ( $\mathrm{ABC}$-alkaline phosphatase), avidin-biotin blocking solution, alkaline phosphatase substrate II reagent, affinity-purified goat anti-biotin antibody, and biotinylated rabbit anti-goat antibody were from Vector Laboratories, Inc. (Burlingame, CA). Monoclonal mouse anti-biotin was from Dako Corp. (Carpinteria, CA). Affinity-purified biotinylated rabbit anti-mouse antibody was from Zymed Laboratories, Inc. (South San Francisco, CA). Xylene and Permount ${ }^{\circledR}$ mounting medium were from Fisher Scientific (Santa Clara, CA).

Remnant kidney disease model. 275-350 g male Munich-Wistar rats were subjected to $5 / 6$ nephrectomy as previously reported (11). Nephrectomized animals were sacrificed and the remnant kidneys harvested at three different times, chosen to correspond to the three morphologic stages characteristic of the renal ablation model. Tissue harvested at 6-14 d after nephrectomy $(n=7)$ represents the early hypertrophic period. Another group was sacrificed at 23-25 d $(n=8)$, representing a period when rapid glomerular growth is complete but when little glomerular injury is apparent by light microscopy. A third group was sacrificed at $69-74 \mathrm{~d}(n=5)$, a period when segmental sclerosis is a prevalent light microscopic finding. Control group animals consisted of normal rats (no surgery, $n=6$ ) and rats subjected to sham nephrectomy $(n=6)$. All animals had free access to standard rat chow and water except for a fourth group of nephrectomized rats $(n=4)$, who postoperatively received the AlI receptor $\left(\mathrm{AT}_{1}\right)$ antoagonist losartan (a generous gift from Dr. Ronald Smith of DuPont/Merck) in the drinking water at $180 \mathrm{mg} / \mathrm{liter}$. This dose was sufficient to maintain the systolic blood pressure between $141-148 \mathrm{~mm} \mathrm{Hg}$ at $10 \mathrm{~d}$ post-operatively and $134-154 \mathrm{~mm} \mathrm{Hg}$ at $17 \mathrm{~d}$, compared with $205-213 \mathrm{~mm} \mathrm{Hg}$ and 224$241 \mathrm{~mm} \mathrm{Hg}$, respectively, in untreated cohorts. The remnant kidneys from this group were harvested at 23-25 d after nephrectomy. At the time of tissue harvesting animals were anesthetized with pentobarbital. The kidneys were perfusion fixed with $4 \%$ paraformaldehyde in PBS, $\mathrm{pH} 7.4$, and cortical tissue blocks were harvested and snap frozen in isopentane cooled with liquid nitrogen. ISRT and histologic studies were performed as described below.

In situ reverse transcription. The ISRT procedure was performed as described in detail (38). In brief, $6 \mu \mathrm{m}$ cryostat sections of perfusionfixed kidney tissue blocks were mounted on slides previously subbed with 2\% 3-aminopropyltriethoxysilane in acetone, fixed in $4 \%$ paraformaldehyde for 20-30 min, and washed with PBS and water. Sections were delipidated with graded ethanol washes, rehydrated, then permeabilized in $0.1 \%$ Triton X-100 (90-105 s). The detergent was neutralized in $100 \mathrm{mM}$ Tris $/ \mathrm{HCl}, \mathrm{pH} 7.4$, followed by an avidin-biotin blocking step, pre-incubation in $100 \mathrm{mM}$ Tris $/ \mathrm{HCl}, \mathrm{pH} 7.4$, and prehybridization for at least $30 \mathrm{~min}$ at room temperature in: $20 \mathrm{mM}$ Tris/HCl, $\mathrm{pH}$ 7.4, $2 \mathrm{mM}$ EDTA, $0.04 \% \mathrm{BSA}, 150 \mathrm{mM} \mathrm{NaCl}, 200 \mu \mathrm{g} / \mathrm{ml}$ yeast tRNA, and $200 \mu \mathrm{g} / \mathrm{ml}$ salmon sperm DNA. Hybridization was then carried out overnight at room temperature in a humidified chamber with specific primers (24-27 mers, $100 \mathrm{ng} / \mathrm{ml}$ of prehybridization solution). Tissues were washed in $1 \times \mathrm{SSC}, \mathrm{pH} 7.0$, followed by a 5 -min pre-incubation in $50 \mathrm{mM}$ Tris $/ \mathrm{HCl}, \mathrm{pH} 8.0,120 \mathrm{mM} \mathrm{KCl}, 10 \mathrm{mM} \mathrm{MgCl}_{2}$. Primer extension was performed at $37^{\circ} \mathrm{C}$ for 90 min using a solution consisting of $50 \mathrm{mM}$ Tris/ $\mathrm{HCl}, \mathrm{pH} 8.0,120 \mathrm{mM} \mathrm{KCl}, 10 \mathrm{mM} \mathrm{MgCl} 2,7.5 \mathrm{mM}$ DTT, $100 \mu \mathrm{g} / \mathrm{ml}$ actinomycin-D, $0.01 \%$ Triton X-100, $120 \mathrm{U} / \mathrm{ml}$ placental ribonuclease inhibitor, $200 \mathrm{U} / \mathrm{ml}$ AMV Reverse Transcriptase, 50 $\mu \mathrm{M}$ biotin-7-dATP, and $600 \mu \mathrm{M}$ each of dCTP, dGTP, and dTTP. After reverse transcription, the sections were washed at room temperature in $1 \times$ SSC, then $0.1 \times$ SSC, and finally PBS. After blocking with $3 \%$ normal rabbit serum, sections were incubated with primary antibody (using either $2 \mu \mathrm{g} / \mathrm{ml}$ goat anti-biotin IgG in $0.1 \%$ BSA in PBS, incubated overnight at $4^{\circ} \mathrm{C}$, or $2 \mu \mathrm{g} / \mathrm{ml}$ monoclonal mouse anti-biotin in $0.1 \%$ BSA in PBS, incubated for $30 \mathrm{~min}$ at $37^{\circ} \mathrm{C}$ ), washed in PBS, and then incubated at $4^{\circ} \mathrm{C}$ for $4 \mathrm{~h}$ with secondary antibody $(5 \mu \mathrm{g} / \mathrm{ml}$ biotinylated rabbit anti-goat IgG or $1.3 \mu \mathrm{g} / \mathrm{ml}$ biotinylated rabbit antimouse in $0.1 \%$ BSA or $0.1 \%$ BSA $/ 2 \%$ rat whole serum in PBS). After washing in PBS, an ABC-peroxidase or ABC-alkaline phosphatase detection system was applied (ABC-alkaline phosphatase application was preceded by a 3-5-min treatment in Bouin's fixative, then washed in PBS), using the corresponding substrate reagent ( $\mathrm{DAB} / \mathrm{NiCl}_{2}$ medium for peroxidase detection, or the alkaline phosphatase substrate reagent). The reaction was terminated at 10-15 min. Slides were then counterstained with methyl green, dehydrated and mounted. Negative controls included performance of ISRT without a specific oligonucleotide primer or with sense primers. All tissue sections were viewed with a Zeiss Axiophöt microscope using Nomarski optics. Serial sections containing at least 20 glomeruli of multiple tissue blocks (usually 3-5) from each experimental animal were examined. To determine semiquantitatively the number of $\alpha$-1(IV) collagen mRNA expressing cells, the number of histochemically stained cells were counted in 25 30 glomerular tufts (80-100 $\mu$ a diameter) from each studied kidney $(n=5-8$, as previously noted). Results are expressed as the mean \pm 1 SD of positive cells per glomerular cross-section.

Oligonucleotide primers. Oligonucleotide primers were synthesized on an Applied Biosystems 391 DNA Synthesizer (Applied Biosystems, Foster City, CA). The primer sequences are as follows: $\alpha$-1(IV) collagen (murine sequence, nucleotides 582-606), 5'-CAACATCTCGCTTCTCTCTATGGTG-3'; angiotensinogen (rat sequence, nucleotides 1452-1477), 5'-GTTATCCACTCTGCCCAGAAAGTGC-3'; fibronectin (rat sequence, nucleotides 265-289), 5'-CTGTGGACTGGAC- 

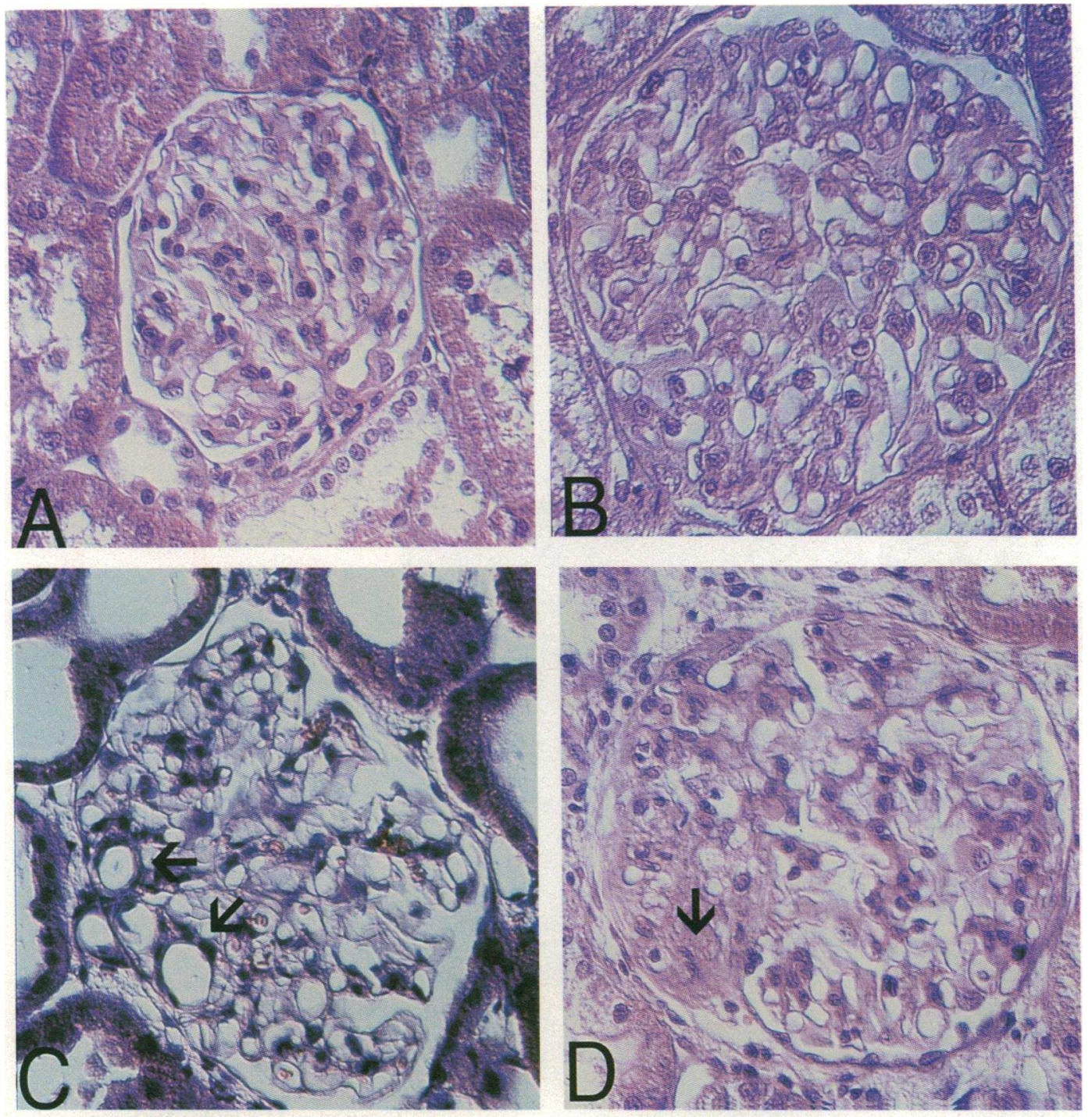

Figure 1. Morphogic evolution of remnant kidneys. 5- $\mu \mathrm{m}$ sections of paraffin-embedded tissue stained with hematoxylin and eosin $(\times 500)$. $(A$, control tissue) The normal glomerulus. $(B)$ A glomerulus from the early post-nephrectomy period $(6-14 \mathrm{~d})$. (C) Intermediate stage glomerulus (23-25 d). Arrows indicate dilated capillary loops not present in the previous stages. $(D)$ Late sclerotic period (69-74 d): demonstrates a segmental sclerotic lesion (arrow) with hyaline deposition, commonly observed at this period.

TCCAATCAGGGG-3'; laminin-B1 (murine sequence, nucleotides 509-532), 5'-CCACACCATTTTCCGATTGCCACC-3'; TGF $\beta-1$ (rat sequence, nucleotides 1422-1446), 5'-TGGTTGTAGAGGGCAAGGACCTTGC-3'. Control primers reflect the matching sense sequences. The sequences of all candidate primers, including control sense primers, were extensively searched against the EMBL and National Institute of Health Genbank databases, and any primers exhibiting high degrees of homology, particularly at the $3^{\prime}$ end, to sequences other than the mRNA of interest were discarded. Additionally, the highly conserved structural motifs found in the TGF- $\beta$ and ECM protein families were avoided, thereby insuring the specificity of the primers used.

Histologic studies. Tissue blocks were fixed in Bouin's fixative, rinsed clear in PBS, and paraffin-embedded. Five micron sections were mounted on gelatin subbed microscope slides and stained with hematoxylin and eosin. Glomerular capillary diameters were assessed in glomerular sections from multiple tissue blocks in controls $(n=6)$, early hypertrophic stage $(n=7)$, and pre-sclerotic stage $(n=8)$ animals. Glomerular cross-sections were viewed through a Zeiss Axiophöt microscope and displayed at $\times 500$ magnification on a Sony Trinitron highresolution video monitor via a Javelin Chromachip II camera. Using the scaled reticle within the microscope as a reference, the least diameter of each capillary cross-section of displayed glomeruli was measured on- screen and recorded. Measurements were repeated in additional glomerular cross-sections in each animal until a minimum of 1,000 capillaries were assessed. The mean capillary diameter in each animal was calculated as the average of the measurements in that animal. The number of capillary diameters in each animal that exceeded $1.5 \times$ and $2.5 \times$ the mean diameter in normals was also calculated.

\section{Results}

Morphologic alterations in remnant kidneys. The progression of glomerular alterations by light microscopy following renal ablation was identical to previous reports (11). The immediate post-operative period was characterized by rapid glomerular expansion and hypertrophy, a process that is maximal between 6-14 d following ablation. This period is referred to as the early stage. Compared with glomeruli from controls (Fig. $1 \mathrm{~A}$; NOTE: in both normal and sham operated controls results of morphologic and ISRT studies were identical), glomeruli obtained $14 \mathrm{~d}$ after ablation exhibited substantial enlargement and many glomerular diameters had increased nearly twofold (Fig. 

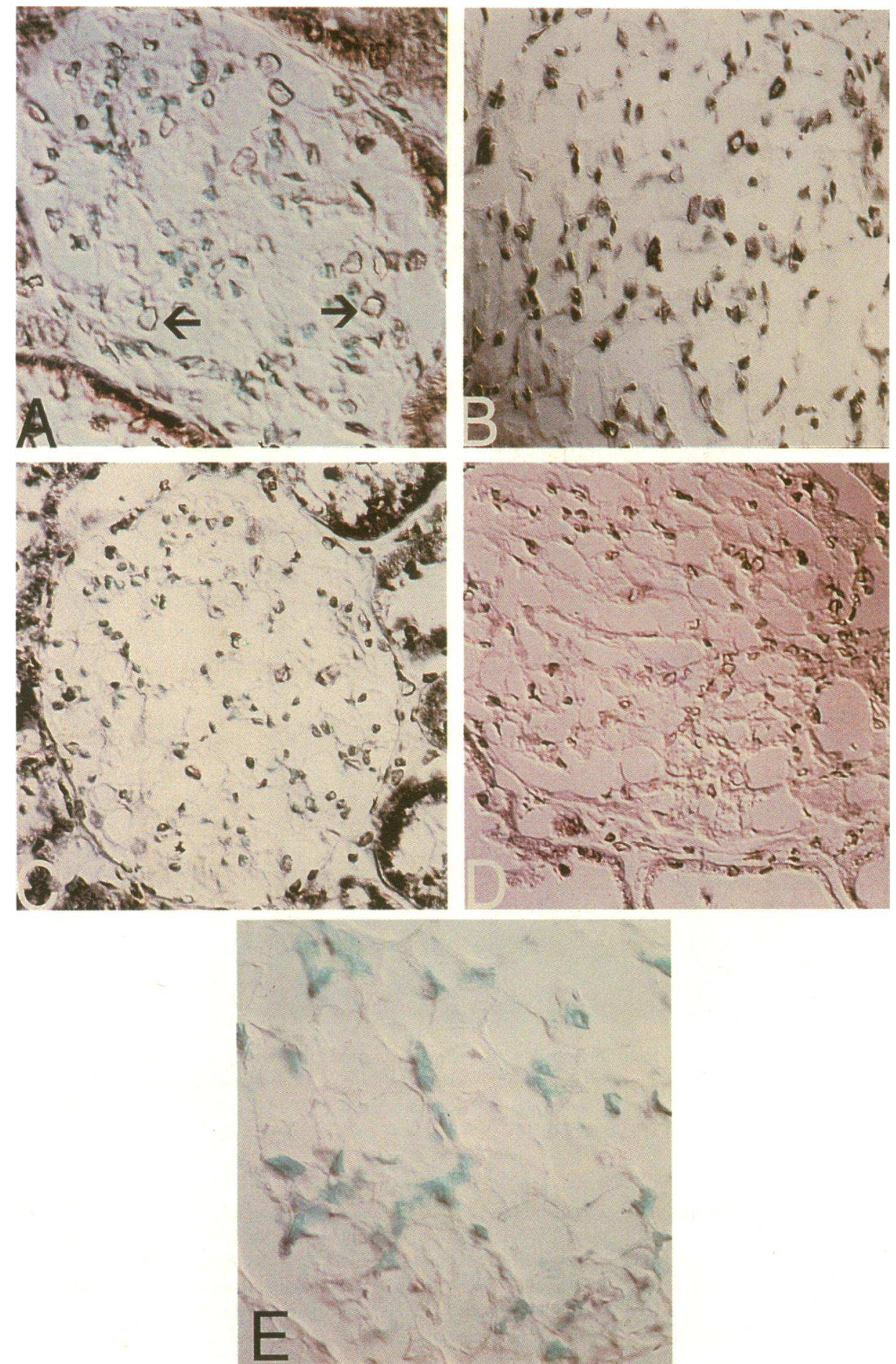

Figure 2. Localization of $\alpha$-1 (IV) collagen mRNA. ( $A$ ) Control glomerulus: dark brown immunoenzymatic reaction product (arrow) is limited to endothelial cells, identifiable by circular, rink-like staining patterns $(\times 500) .(B)$ Early post-nephrectomy stage: global expression by all glomerular cell types is observed at $14 \mathrm{~d}$ in this hypertrophic glomerulus $(\times 400) .(C)$ Intermediate stage: compared with the previous panel, $\alpha-1$ (IV) collagen mRNA is detected within substantially fewer cells $(\times 400) .(D)$ Late sclerotic stage: scattered endothelial staining is detected with no significant concentration within an area of segmental sclerosis $(\times 400)$. (E) ISRT localization for $\alpha$-1 (IV) collagen mRNA using a sense DNA primer: the lack of staining is representative of all negative control ISRT studies $(\times 1,200)$
$1 B$ ). In spite of this rapid increase in size, overall glomerular structure, and architecture remained relatively intact. Specifically, capillary loop diameters remained unchanged and relatively uniform in size with respect to controls. The average capillary diameter in controls was $4 \mu \mathrm{m}$, consistent with previously published results $(39,40)$, and only $1.2 \%$ of the diameters exceeded $6 \mu \mathrm{m}$. Similar results were observed in early stage glomeruli (average diameter $4 \mu \mathrm{m}$ with $1.4 \%$ of loops exceeding $6 \mu \mathrm{m})$. No diameters exceeded $10 \mu \mathrm{m}$ in either group. The compensatory hypertrophic response stabilized by $23-25 \mathrm{~d}$ (referred to as the intermediate or pre-sclerotic stage ), as no further increases in glomerular size were observed. However, there was apparent dilation of a small number of capillary loops (Fig. 1 $C$ ), especially prominent near the vascular poles, which slightly increased the average diameter to $4.5 \mu \mathrm{m}$. Particularly notable, however, was that $10.1 \%$ of the diameters exceeded $6 \mu \mathrm{m}$ and $3.1 \%$ exceeded $10 \mu \mathrm{m}$. The resulting heterogeneity in capillary loop size contrasted markedly with the uniformity observed in the previous two groups. Occasional glomeruli exhibited mild focal alterations in glomerular architecture, which generally consisted of mesangial hypercellularity, as well as mild mesangial matrix expansion. By $10 \mathrm{wk}$ after ablation, referred to as 

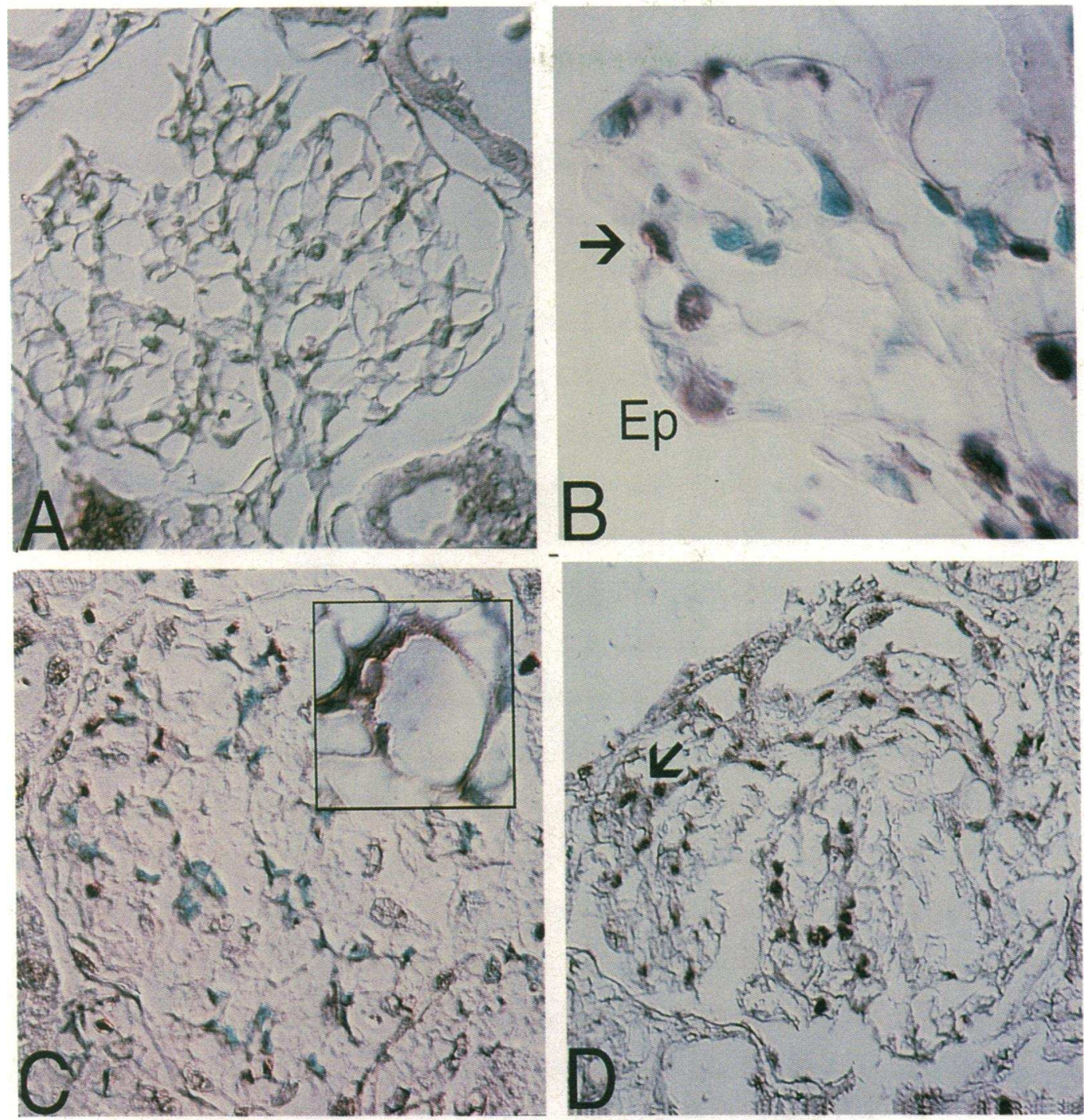

Figure 3. Localization of laminin B1 mRNA. (A) Control glomerulus: laminin B1 mRNA localizes to the mesangial regions $(\times 500) .(B)$ Early post-nephrectomy period: staining for laminin B1 mRNA is observed within an epithelial cell (Ep), located along the outer periphery of capillary loops, as well as within a mesangial cell (arrow; $\times 1,800)$. $(C)$ Intermediate stage: laminin B1 mRNA staining present in a predominantly mesangial cell distribution $(\times 500)$. The inset demonstrates endothelial cell expression not present in the earlier stages $(\times 1,800)$. (D) Late sclerotic stage: staining is concentrated within endothelial and mesangial cells within an area of sclerosis (arrow; $\times 500)$.

the late sclerotic stage, extensive segmental sclerosis in various degrees of evolution was observed in the majority of glomeruli (Fig. $1 D)$.

Patterns of matrix protein gene expression. In a previous ISRT study (38), which localized the mRNAs of nine major glomerular matrix proteins in the mature rat, we demonstrated the asymmetric nature of glomerular basement membrane (GBM) protein synthesis and the contribution of all three glomerular cell types to this process. Notable in this study was the relatively limited cellular distribution of fibronectin (mesangial cells), laminin B1 (mesangial cells), and $\alpha-1$ (IV) collagen (endothelial cells) mRNAs. The distribution of $\alpha$-1(IV) collagen mRNA was highly restricted, appearing in only a subset of endothelial cells lining capillary lumina of small diameter. In applying ISRT to the renal ablation model, we reasoned that changing cellular patterns of matrix protein gene expression would be more readily detected by studying mRNAs normally limited in their range of expression. Thus, primers to detect $\alpha$ -
1(IV) collagen, laminin B1, and fibronectin mRNAs were chosen for the studies described herein.

The mRNAs for $\alpha-1$ (IV) collagen, the major structural GBM component, was found only within a limited subset of endothelial cells in control animals (Fig. $2 \mathrm{~A}$ ) with an average of $12 \pm 4$ positively stained cells per glomerular cross-section. This pattern changed dramatically in both number and distribution following renal ablation. At $14 \mathrm{~d}$ after ablation $\alpha$-1(IV) collagen mRNA was detected in all three glomerular cells types (i.e., mesangial, epithelial, and endothelial) with $52 \pm 17$ cells per glomerular cross-section expressing this RNA transcript (Fig. $2 B$ ). By $24 \mathrm{~d}$ after ablation, $\alpha$-1(IV) collagen mRNA was detected in relatively fewer cells $(24 \pm 8$ cells per glomerular cross-section), demonstrating an association between the stabilization of glomerular hypertrophy and the reversal of the previously augmented expression of this mRNA (Fig. $2 C$ ). The overall distribution of cells positive for $\alpha$-1(IV) collagen mRNA diminished further as segmental sclerosis appeared, and 

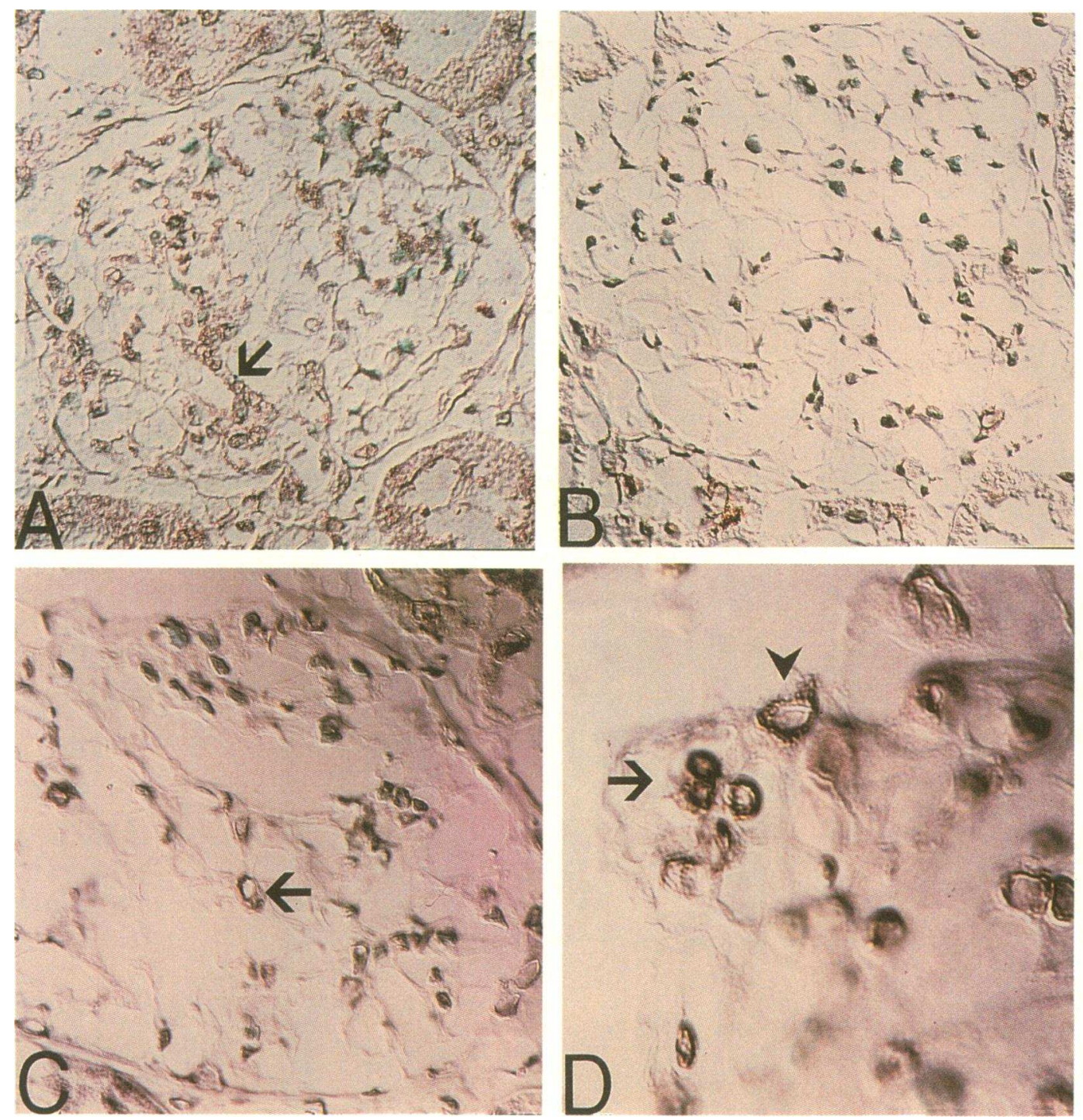

Figure 4. Localization of fibronectin mRNA. (A) Control glomerulus: staining for fibronectin mRNA is observed along a mesangial stalk (arrow) and in peripheral mesangial areas $(\times 500)$. $(B)$ Early post-nephrectomy period: mesangial staining pattern is unchanged $(\times 500) .(C)$ Intermediate period: mesangial cell expression persists, but fibronectin mRNA is also detected in endothelial cells (arrow; $\times 500)$. (D) Late sclerotic stage: endothelial fibronectin mRNA expression present within several endothelial cells (arrowhead), as well as in an adjacent mesangial cell cluster (arrow; $\times 500)$.

by $69 \mathrm{~d}$ after ablation $\alpha-1$ (IV) collagen expression resembled the patterns of limited, heterogeneous endothelial cell expression ( $19 \pm 5$ cells per glomerular cross-section) seen in control animals (Fig. $2 D$ ). Notably, areas of evolving segmental sclerosis did not exhibit any significant $\alpha$-1(IV) collagen mRNA expression.

Laminin B1 mRNA in control animals was restricted to the mesangium (Fig. $3 A$ ), consistent with our previous findings for this matrix protein component (38). As with $\alpha$-1(IV) collagen mRNA, laminin B1 mRNA expression and distribution changed significantly during the hypertrophic period following ablation. At 6 days following ablation visceral glomerular epithelial cells, which normally do not express laminin B1, were observed to express this mRNA (Fig. 3 B). By day 24 laminin B1 mRNA was no longer present in visceral epithelial cells, while, for the first time, endothelial cell expression was evident (Fig. $3 C$ ). In contrast to $\alpha-1$ (IV) collagen mRNA, laminin B1 mRNA was prominently expressed during the late sclerotic stage. At $74 \mathrm{~d}$ following renal ablation the mRNA for this protein localized within both mesangial and endothelial cells and was especially prominent in areas of segmental sclerosis (Fig. $3 \mathrm{D}$ ).

The cellular distribution of fibronectin mRNA during the early stage of glomerular hypertrophy contrasted markedly with the augmented cellular expression patterns observed for $\alpha$ 1(IV) collagen and laminin B1 mRNAs. Fibronectin mRNA distribution, normally limited to mesangial cells (Fig. $4 A$ ), remained relatively unchanged during the development of glomerular hypertrophy (Fig. $4 B$ ). By the pre-sclerotic stage occasional endothelial cells stained positive for fibronectin mRNA (Fig. $4 C$ ). This became much more pronounced as sclerosis developed. By $74 \mathrm{~d}$ after following ablation fibronectin mRNA staining was observed within both mesangial and endothelial cells with particularly heavy staining patterns noted in foci of sclerotic injury (Fig. $4 D$ ).

Angiotensinogen and TGF- $\beta 1$ gene expression in remnant kidneys. Significant differences between the glomerular patterns 

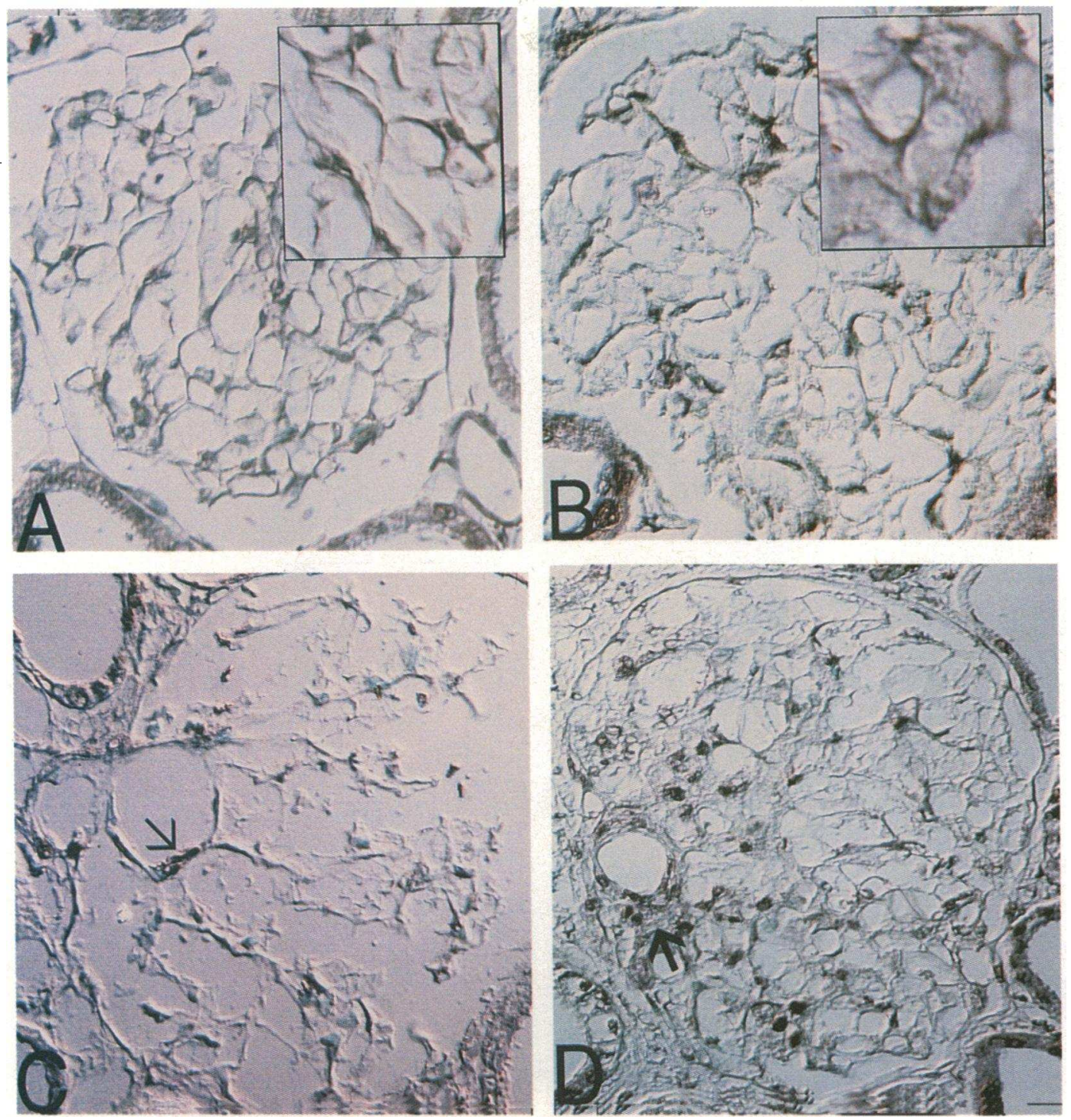

Figure 5. Localization of angiotensinogen mRNA. $(A)$ Scattered staining for angiotensinogen mRNA is observed in a control glomerulus $(\times 500)$, which does not change in the early post-nephrectomy stage $(B ; \times 500)$. Insets in the two panels show areas adjacent to the vascular poles, showing only mesangial cell staining and no staining along capillary loops $(\times 1,200) .(C)$ Intermediate stage: baseline mesangial cell expression persists, but angiotensinogen mRNA is also localized along the walls of dilated capillary loops (arrow; $\times 400)$. $(D)$ Late sclerotic stage: dense staining for angiotensinogen mRNA is seen in a large segmental sclerotic lesion (arrow), localizing to both endothelial and mesangial cells $(\times 400)$.

of TGF- $\beta 1$ and angiotensinogen mRNA expression were noted following subtotal renal ablation. In controls angiotensinogen mRNA staining was limited to a scattered mesangial cell distribution (Fig. $5 \mathrm{~A}$ ). In contrast, TGF- $\beta 1$ mRNA was found in a significant fraction of mesangial cells within each glomerulus (Fig. $6 \mathrm{~A}$ ), a pattern that we have previously reported (23). There were no significant changes in the distribution of angiotensinogen and TGF- $\beta 1$ mRNA staining during the early stage following renal ablation (Figs. $5 B$ and $6 B$, respectively), while rather dramatic alterations were observed at day 24 . At this presclerotic stage mRNAs for angiotensinogen were found within the endothelial cells lining dilated capillary loops at the vascular pole (Fig. $5 \mathrm{C}$ ). The expression of angiotensinogen mRNA within the endothelium of these enlarged capillary loops was occasionally accompanied by prominent angiotensinogen mRNA staining within neighboring mesangial cells. TGF- $\beta 1$ mRNA expression and distribution were also dramatically altered at $24 \mathrm{~d}$ after ablation. As with angiotensinogen mRNA,
TGF- $\beta 1$ mRNA staining was detected within the endothelium of widened capillary loops, in addition to surrounding mesangial cells (Fig. $6 C$ ). Additional ISRT analyses on consecutive tissue sections, alternating between angiotensinogen and TGF- $\beta 1$ mRNA detection, revealed these two mRNAs co-localizing to the same endothelial and mesangial cells during this pre-sclerotic stage (Fig. 7, $A$ and $B$ ). Even more extensive staining for these two mRNAs was noted as the disease process progressed. In the glomeruli from rats sacrificed $74 \mathrm{~d}$ after renal ablation, both angiotensinogen (Fig. $5 D$ ) and TGF- $\beta 1$ (Fig. $6 D$ ) mRNAs were evident within numerous mesangial and endothelial cells located within and around evolving sclerotic foci.

The association between angiotensinogen and TGF- $\beta 1$ mRNA expression was further investigated by examining the effects of losartan administration, which was started at the time of renal ablation. Losartan is a noncompetitive inhibitor of $\mathrm{AT}_{1}$ receptors (41), and the treatment regimen used in this study has previously been shown to inhibit the development of segmental 

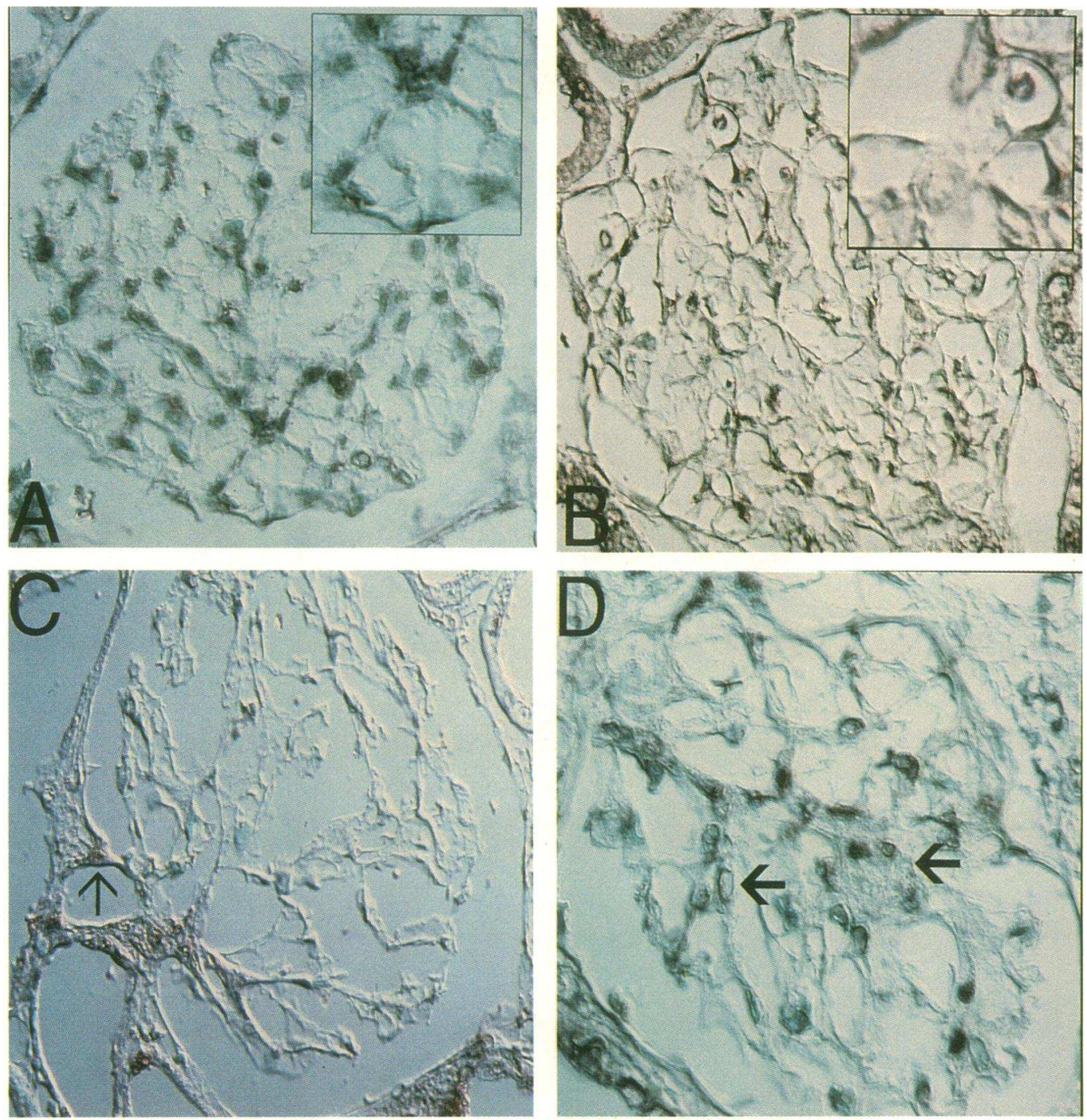

Figure 6. Localization of TGF- $\beta 1$ mRNA. ( $A$ ) Control glomerulus: TGF- $\beta 1$ mRNA prominently localizes to a majority of mesangial cells $(\times 500)$. $(B)$ Early post-nephrectomy stage: TGF- $\beta 1 \mathrm{mRNA}$ expression remains restricted to mesangial cells $(\times 400)$. Insets for $A$ and $B$ represent areas adjacent to the vascular poles, showing mesangial cell staining without staining in these normal sized capillary loops $(\times 1,500)$. $(C)$ Intermediate stage: TGF- $\beta 1 \mathrm{mRNA}$ localizes along a widened capillary loop (arrow), in addition to an immediately adjacent area of mesangial expansion $(\times 400)$. (D) Late sclerotic stage: heavy staining for TGF- $\beta 1$ mRNA is observed within a central sclerotic focus (arrow), involving both mesangial and endothelial cells $(\times 600)$.

sclerosis $10 \mathrm{wk}$ after 5/6 nephrectomy (7). Losartan treated animals were studied with ISRT at $24 \mathrm{~d}$ after ablation, coinciding with the earliest observed changes in angiotensinogen and TGF- $\beta 1$ mRNA expression in untreated animals. In glomeruli from treated animals angiotensinogen (Fig. $7 C$ ) and TGF- $\beta 1$ (Fig. $7 D$ ) mRNAs were primarily limited to a sparse, scattered mesangial cell distribution. Rare endothelial cell staining of angiotensinogen mRNA was observed, and TGF- $\beta 1$ mRNA was virtually absent from the endothelium. These patterns contrasted markedly with those observed in the untreated cohorts (Fig. 7, $A$ and $B$ ). In addition, losartan treatment blocked the abnormal expression of laminin $\mathrm{B} 1$ and fibronectin mRNAs by the endothelium (Fig. 8).

\section{Discussion}

The morphologic transformations that characterize the remnant kidney model result from an evolving series of phenotypic alter- ations in one or more of the intrinsic glomerular cells. Improved mRNA localization methodologies provide new insights into evaluating these phenotypic changes. Since complete dissociation of mRNA expression from synthesis of its protein translation product occurs in only rare instances, information obtained from such techniques can also provide persuasive evidence for the cellular origins of proteins within the glomerulus (38).

The early post-ablation period is an adaptive compensatory response that is associated with a rapid increase in glomerular size. Our findings of augmented $\alpha-1$ (IV) collagen and laminin B1 gene expression by multiple cell types suggest that the demands of new GBM synthesis during this hypertrophic process lead to the recruitment of additional cell types to synthesize these critical component proteins. As a principal structural component of the normal GBM, the increased synthesis of $\alpha$-1(IV) collagen during this early period is not an unexpected finding. The enhanced epithelial cell synthesis of laminin B1 is unexpected, since in the mature glomerulus laminin B1 is present 

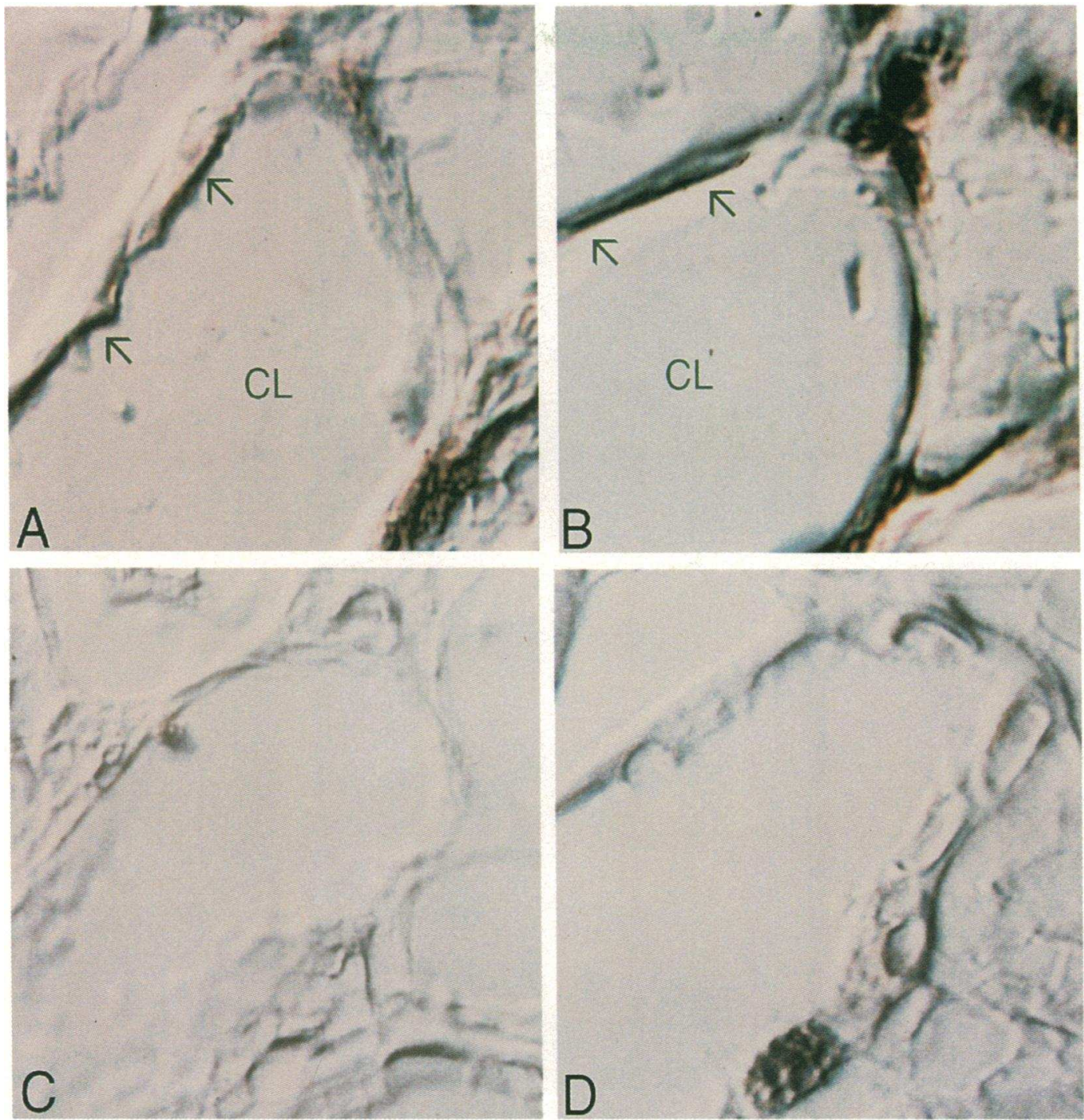

Figure 7. Angiotensinogen and TGF- $\beta 1$ mRNA localization in consecutive sections $(A$ and $B)$ and after $\mathrm{AT}_{1}$ receptor blockade $(C$ and $D)$. Tissue was obtained $24 \mathrm{~d}$ after nephrectomy. ( $A$ ) Staining for angiotensinogen mRNA is observed along the wall of a dilated capillary loop wall (arrow; $\mathrm{CL}$, capillary loop) and in the adjacent mesangial cell cluster $(\times 2,500)$. $(B)$ In the contiguous section TGF- $\beta 1 \mathrm{mRNA}$ staining is present in an identical pattern (arrow; $\times 2,500$ ). $C$ and $D$ : Staining for angiotensinogen $(C)$ and TGF- $\beta 1(D)$ mRNA in tissue from animals given losartan in the drinking water after nephrectomy $(\times 2,500)$.

only in the mesangial matrix and not within the GBM (42). Data obtained from Northern blot (43), in situ hybridization (44), and immunohistochemical studies (45) all suggest that the laminin B1 protein is a major basement membrane component in the developing glomeruli of fetal and newborn rats. Immunolocalization studies have also shown that $\alpha$-1(IV) collagen is synthesized by multiple glomerular cell types during development $(43,46,47)$. Therefore, in at least these two respects, the early glomerular response to subtotal renal ablation represents a recapitulation of fetal patterns of GBM synthesis.

In the intermediate pre-sclerotic phase, expression of $\alpha$ 1 (IV) collagen mRNA approached its baseline pattern, coinciding with the stabilization of hypertrophy. During this period, however, the first sign of pathologically significant shifts in cellular matrix synthesis patterns was detected, namely, the appearance of fibronectin and laminin B1mRNAs within endothelial cells. The endothelial cell expression of fibronectin becomes more extensive as segmental sclerosis develops, as evidenced by the fibronectin mRNA staining within nearly all endothelial and mesangial cells within sclerotic foci. These mRNA localization results corroborate immunohistochemical studies demonstrating heavy fibronectin staining within the glomerular sclerotic lesions after renal ablation (48). In addition to endothelial and mesangial expression of fibronectin within sclerotic foci, laminin B1 mRNA expression followed a similar pattern, suggesting that this protein is a substantial component of sclerotic lesions as well. In contrast, mRNAs for $\alpha$-1 (IV) collagen were conspicuously absent in these advanced lesions.

These mRNA localization patterns demonstrate that the major phases of the glomerular morphologic response to subtotal renal ablation are associated with distinct cellular patterns of matrix protein gene expression. The early compensatory hypertrophy is characterized by global recruitment of diverse cell types to synthesize $\alpha$-1 (IV) collagen. This response is transient. At $10 \mathrm{wk}$ after ablation, after hypertrophy has ceased, an entirely different pattern of matrix protein expression supervenes, characterized by extensive endothelial cell expression of fibronectin and laminin B1 mRNA. Since segmental glomerular sclerosis 

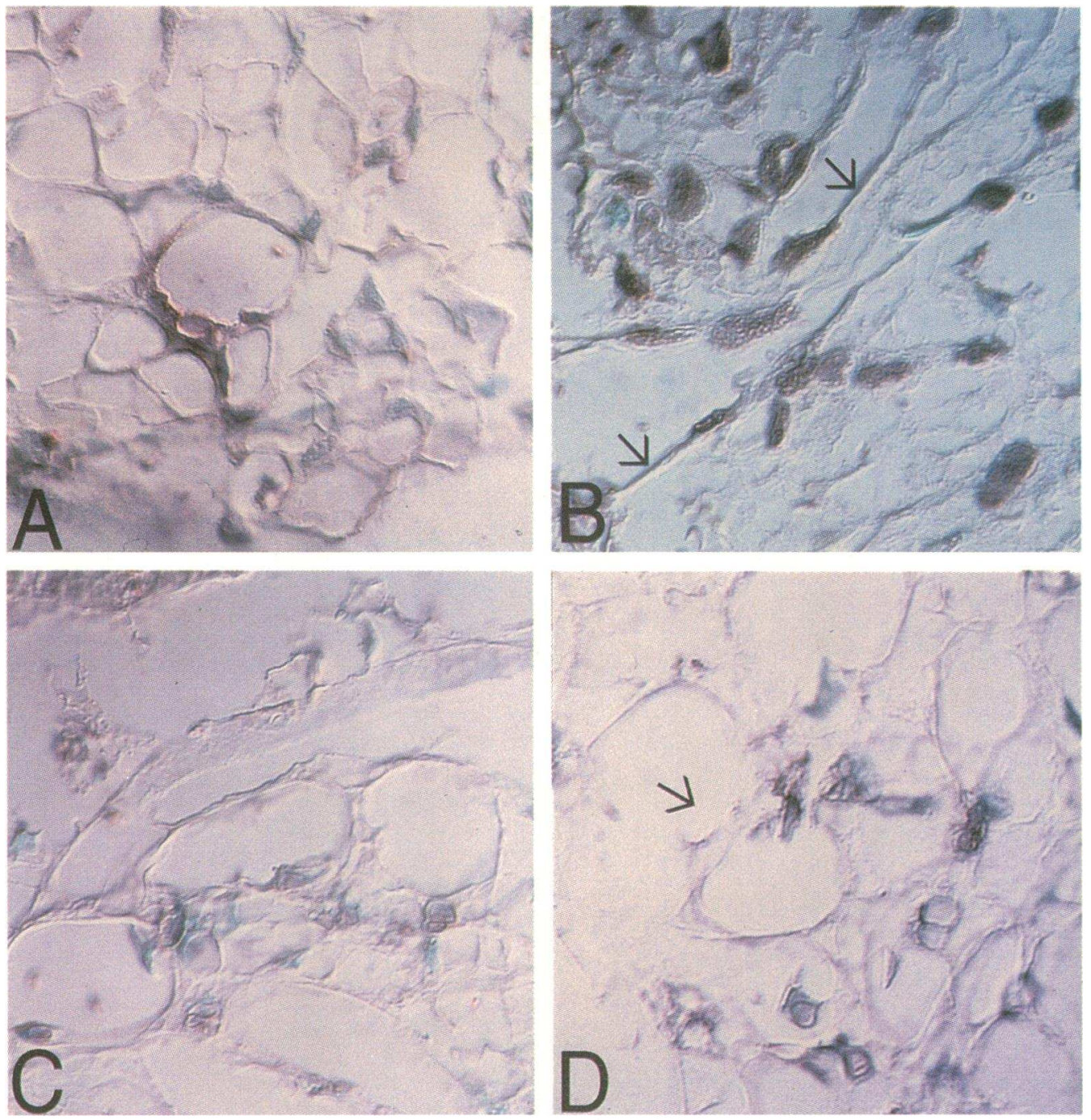

Figure 8. Laminin $\mathrm{B} 1$ and fibronectin mRNA expression following $\mathrm{AT}_{1}$ receptor blockade. Tissue was obtained $24 \mathrm{~d}$ after nephrectomy. ( $A$ ) Endothelial cell expression of laminin B1 mRNA is observed in an untreated remnant kidney $(\times 1,800$, NB: a portion of this photograph appears as an inset in Fig. 3). (B) Staining for fibronectin mRNA extends along the wall of an enlarged capillary (arrows, $\times 1,800)$. Endothelial cell expression of laminin B1 $(C)$ and fibronectin $(D)$ mRNA is not detected in animals treated with losartan $(\times 1,800)$.

and progressive renal failure are the ultimate result of subtotal renal ablation, this late response, characterized by discoordinate matrix protein gene expression, can be considered maladaptive.

Angiotensinogen and TGF- $\beta 1 \mathrm{mRNA}$ expression only became more prevalent when the glomerular growth following renal ablation had stabilized. Particularly significant was the appearance of both mRNAs within the endothelial cells lining dilated capillary loops, as well as their co-localization within the same cells. Focal augmentation in mesangial cell angiotensinogen mRNA expression was also observed, but only in the context of adjacent endothelial cell expression.

Recent studies, using another model of glomerular sclerosis (uninephrectomy in young rats, references 37 and 49), have demonstrated that the capillary loop dilation following renal ablation is associated with a number of ultrastructural abnormalities in endothelial cells, as well as in adjacent mesangial cells and podocytes. These capillary loop alterations occurred primarily near the vascular pole and most frequently involved the first branches of afferent arterioles. This is consistent with our current light microscopic findings. It was furthermore noted that glomerular tuft adhesions and sclerosis eventually developed at these same locations, demonstrating an association between the dilation and injury of the endothelium and the subsequent development of segmental glomerular sclerosis. These studies, in conjunction with our data for angiotensinogen, TGF- $\beta 1$, fibronectin, and laminin B1 mRNA localization, suggest that endothelial cell injury, or activation, mediates the alterations in glomerular cell biology that ultimately result in segmental sclerosis.

Capillary dilation following renal ablation may result from a number of hemodynamic alterations. One consistent finding following subtotal renal ablation is glomerular capillary hypertension. Results from numerous studies have established that this is a critical pathophysiologic component in the development of sclerosis (4-11). Increased capillary pressure is a possible stimulus for the phenotypic changes observed in this study. An effect of increased capillary pressure is an increase in capillary wall tension, particularly in capillaries with increased diameters. The appearance of angiotensinogen and TGF- $\beta 1 \mathrm{mRNA}$ expression, primarily along widened capillary loops, coincides with areas of increased wall tension, suggesting that this may also be a stimulus for angiotensinogen and TGF- $\beta 1$ expression. Change in fluid shear stress is a third possible outcome of 
structural alterations in capillary loops, and recent studies have demonstrated activation of endothelial cell gene transcription in response to such changes $(50,51)$. Fluid shear stress can result in increased endothelial expression of platelet-derived growth factor (PDGF), a response that is critically dependent upon a hexanucleotide motif contained within the promoter region of the PDGF gene (51). Particularly relevant to this study is the presence of this motif within the promoter region of the TGF- $\beta 1$ gene (51) and in regions of the angiotensinogen gene that are common binding locations for transcription factors. This current study suggests that hemodynamic factors, widely implicated as a cause of glomerular sclerosis, provide the initial stimulus for endothelial angiotensinogen and TGF- $\beta 1 \mathrm{mRNA}$ expression. The relative importance of these factors in the pathophysiology of this process, however, is not directly addressed by the findings in this study.

In addition to stimulating TGF- $\beta 1$ expression, AII has also been shown to mediate the expression of a number of other cytokines and growth factors, including PDGF $(14,52)$ and basic fibroblast growth factor (52). In particular, transient increases in PDGF expression have been observed during the early stages after subtotal renal ablation (53), a response that can be diminished by inhibiting angiotensin converting enzyme activity (54). This suggests that PDGF may also have a prominent role in the pathophysiology of this process. Therefore, the endothelial cell expression of angiotensinogen mRNA that we observed following renal ablation is likely to induce the expression of other cytokines, in addition to TGF- $\beta 1$, that may be important in the development of glomerular sclerosis. In this study we have focused our attention on TGF- $\beta 1$ expression, since this protein has been clearly linked to the development and progression of sclerosis in numerous glomerular disease models (25-31).

Although ISRT does not quantify levels of mRNA expression, other recent investigations support our findings which suggest that locally generated AII induces glomerular TGF- $\beta 1$, and hence, ECM protein mRNA expression. Border and colleagues (55) have observed increased TGF- $\beta 1$ and fibronectin mRNA levels (6.1- and 4.0-fold, respectively, at $8 \mathrm{~h}$ ) by cultured mesangial cells in response to AII treatment. This response could be prevented by AII receptor antagonists. In addition, AII enhanced the conversion of latent TGF- $\beta 1$ into its biologically active form. In the renal ablation model Juanid et al. (56), used Northern blot analysis of total glomerular RNA to measure the temporal changes in TGF- $\beta 1$ mRNA levels and the effects of losartan on these changes. In this study AII receptor blockade reduced TGF- $\beta 1$ mRNA levels by $>50 \%$ compared with controls. Furthermore, Schunkert et al. (57), have demonstrated increased kidney angiotensinogen mRNA expression in response to intravenous AII infusions, consistent with our observation of diminished angiotensinogen mRNA expression with AII receptor blockade. In addition to corroborating these prior measurements, our results provide insightful cellular localization information unobtainable by Northern blot analyses.

Dzau and colleagues have provided evidence that paracrine/ autocrine interactions between endothelial and smooth muscle cells are important in normal vascular physiology. They have also demonstrated that such interactions are also critical in vascular disease processes $(33,36,58)$. This endothelial-smooth muscle interdependency may be particularly relevant to glomerular disease, as the glomerular mesangial cell and the vascular smooth muscle cell share many common features $(6,53,59)$. Thus, our findings also indicate that mesangial cell-endothelial cell communication is critical in the development of segmental glomerular sclerosis.

As the interface between the blood and remaining glomerular tissue, the glomerular endothelium is ideally situated to serve as a principal mediator of renal disease processes. As the understanding of endothelial cell biology expands, traditional views of the glomerular endothelium as a biologically inert cell layer becomes increasingly untenable. Difficulties in maintaining pure glomerular endothelial cell cultures have, unfortunately, limited investigations in this area, and extensive evidence for endothelial involvement in glomerular disease is lacking. The results of this study do, however, establish that induction of TGF- $\beta 1$, fibronectin, and laminin B1 mRNA expression by the glomerular endothelium may be important in the progression of glomerular disease. Our findings have also provided insights regarding the role of AII in glomerular sclerosis, demonstrating the cellular origins of this hormone in relation to the altered glomerular capillary architecture found subsequent to renal ablation. The initial pathophysiologic stimulus of hemodynamic injury to the endothelium results in local AII generation, presumably resulting from endothelial expression of angiotensinogen. This locally generated AII acts on adjacent mesangial and additional endothelial cells, inducing the expression of TGF- $\beta 1$ and, possibly, other cytokines and growth factors. The selfamplifying properties of these agents result in a cascade of growth factor synthesis which, ultimately, lead to uncontrolled matrix protein accumulation characteristic of the segmental glomerular sclerotic lesion.

\section{Acknowledgments}

These studies were supported by Public Health Service Grants grants DK-39776, DK-31398, DK-02199, DK-37423, T32 DK-07219 and the Baxter Healthcare Extramural Grant Program.

\section{References}

1. Rennke, H. G., and P. S. Klein. 1989. Pathogenesis and significance of nonprimary focal and segmental glomerulosclerosis. Am. J. Kidney Dis. 13(6): $443-456$.

2. Adler, S., L. J. Striker, G. E. Striker, D. T. Perkinson, J. Hibbert, and W. G. Couser. 1986. Studies of progressive glomerular sclerosis in the rat. Am. J. Path. 123(3):553-562.

3. Waldherr, R., and N. Gretz. 1988. Natural course of the development of histological lesions after 5/6 nephrectomy. Contr. Nephrol. 60:64-72.

4. Fogo, A., and I. Ichikawa. 1989. Evidence for the central role of glomerular growth promoters in the development of sclerosis. Semin Nephrology. 9(4):329342.

5. Olson, J. L., and R. H. Heptinstall. 1988. Nonimmunologic mechanisms of glomerular injury. Lab. Invest. 59(5):564-578.

6. Diamond, J. R., and M. J. Karnovsky. 1988. Focal and segmental glomerulosclerosis: analogies to atherosclerosis. Kidney Int. 33:917-924.

7. Lafayette, R. A., G. Mayer, S. K. Park, and T. W. Meyer. 1992. Angiotensin II receptor blockade limits glomerular injury in rats with reduced renal mass. $J$. Clin. Invest. 90(3):766-771.

8. Mayer, G., R. A. Lafayette, J. Oliver, W. M. Deen, B. D. Myers, and T. W. Meyer. 1993. Effects of angiotensin II receptor blockade on remnent glomerular permselectivity. Kidney Int. 43:346-353.

9. Anderson, S., T. W. Meyer, H. G. Rennke, and B. M. Brenner. 1985. Control of glomerular hypertension limits glomerular injury in rats with reduced renal mass. J. Clin. Invest. 76:612-619.

10. Ikoma, M., T. Kawamura, Y. Kakinuma, A. Fogo, and I. Ichikawa. 1991. Cause of variable therapeutic efficiency of angiotensin converting enzyme inhibitor on glomerular lesions. Kidney Int. 40:195-202.

11. Meyer, T. W., S. Anderson, H. G. Rennke, and B. M. Brenner. 1987. Reversing glomerular hypertension stabilizes established glomerular injury. Kidney Int. 31:752-759.

12. Dzau, V. J., and J. R. Ingelfinger. 1989. Molecular biology and pathophysiology of the intrarenal renin-angiotensinogen system. J. Hypertension. 7:S3-S8. 
13. Anderson, P. W., Y. S. Do, and W. A. Hsueh. 1993. Angiotensin II causes mesangial cell hypertrophy. Hypertension. 21 (1):29-35.

14. Hahn, A. W. A., T. J. Resnick, J. Bernhardt, F. Ferracin, and F. R. Bühler 1991. Stimulation of autocrine platelet-derived growth factor AA-homodimer and transforming growth factor $\beta$ in vascular smooth muscle cells. Biochem. Biophys. Res. Commun. 178:1451-1458.

15. Stouffer, G. A., and G. K. Owens. 1992. Angiotensin II-induced mitogenesis of spontaneously hypertensive rat-derived cultured smooth muscle cells is dependent on autocrine production of transforming growth factor- $\beta$. Circ. Res. $70: 820-828$.

16. Nathan, C., and M. Sporn. 1991. Cytokines in context. J. Cell Biol. 113(5):981-986.

17. MacKay, K., L. J. Striker, J. W. Stauffer, T. Doi, L. Y. Agodoa, and G. E. Striker. 1989. Transforming growth factor- $\beta$ : murine glomerular receptors and responses of isolated glomerular cells. J. Clin. Invest. 83:1160-1167.

18. Adler, S., X. Chen, and B. Eng. 1990. Control of rat glomerular epithelial cell growth in vitro. Kidney Int. 37:1048-1054.

19. Floege, J., N. Topley, and K. Resch. 1991. Regulation of mesangial cell proliferation. Am. J. Kidney Dis. 17(6):673-676.

20. Border, W. A., S. Okuda, L. R. Languino, and E. Ruoslahti. 1990. Transforming growth factor- $\beta$ regulates production of proteoglycans by mesangial cells. Kidney Int. 37:689-695.

21. Nakamura, T., D. Miller, E. Ruoslahti, and W. A. Border. 1992. Production of extracellular matrix by glomerular epithelial cells is regulated by transforming growth factor- $\beta 1$. Kidney Int. 41:1213-1221.

22. Edwards, D. R., G. Murphy, J. J. Reynolds, S. E. Whitham, J. P. Docherty, P. Angel, and J. K. Heath. 1987. Transforming growth factor beta modulates the expression of collagenase and metalloproteinase inhibitor. EMBO (Eur. Mol. Biol. Organ.) J. 6(7):1899-1904.

23. Marti, H. P., L. Lee, M. Kashgarian, and D. H. Lovett. 1993. Transforming growth factor- $\beta 1$ stimulates glomerular mesangial cell synthesis of the $72 \mathrm{kDa}$ Type IV collagenase. Am. J. Pathol. In press.

24. Kim, S.-J., F. Denhez, K. Y. Kim, J. T. Holt, M. B. Sporn, and A. B Roberts. 1989. Activation of the second promotor of the transforming growth factor- $\beta 1$ gene by transforming growth factor- $\beta 1$ and phorbol ester occurs through the same target sequences. J. Biol. Chem. 264(32):19373-19378.

25. Border, W. A., S. Okuda, L. R. Languino, M. B. Sporn, and E. Ruoslahti. 1990. Suppression of experimental glomerulonephritis by antiserum against transforming growth factor $\beta 1$. Nature (Lond.). 346:371-374.

26. Border, W. A., S. Okuda, T. Nakamura, L. R. Languino, and E. Ruoslahti. 1991. Role of TFG- $\beta 1$ in experimental glomerulonephritis. Ciba Foundation Symposium. 157:178-193.

27. Border, W. A., N. A. Noble, T. Yamamoto, J. R. Harper, Y. Yamaguchi, M. D. Pierschbacher, and E. Ruoslahti. 1992. Natural inhibitor of transforming growth factor- $\beta$ protects against scarring in experimental kidney disease. Nature (Lond.). 360:361-364.

28. Okuda, S., L. R. Languino, E. Ruoslahti, and W. A. Border. 1990. Elevated expression of transforming growth factor $-\beta$ and proteoglycan production in experimental glomerulonephritis: possible role in expansion of the mesangial extracellular matrix. J. Clin. Invest. 86:453-462.

29. Border, W. A., and E. Ruoslahti. 1992. Transforming growth factor- $\beta$ in disease: the dark side of tissue repair. J. Clin. Invest. 90:1-7.

30. Coimbra, T., R. Wiggins, J. W. Noh, S. Merritt, and S. H. Phan. 1991 Transforming growth factor $-\beta$ production in anti-glomerular basement membrane disease in the rabbit. Am. J. Pathol. 138(1):223-234.

31. Yamamoto, T., T. Nakamura, N. A. Noble, E. Ruoslahti, and W. A Border. 1993. Expression of transforming growth factor $\beta$ is elevated in human and experimental diabetic nephropathy. Proc. Natl. Acad. Sci. USA. 90:18141818.

32. MacKay, K., P. Kondaiah, D. Danielpour, H. A. Austin, and P. D. Brown 1990. Expression of transforming growth factor- $\beta 1$ and $-\beta 2$ in rat glomeruli. Kidney Int. 38:1095-110.

33. Dzau, V. J., and G. H. Gibbons. 1991. Endothelium and growth factors in vascular remodeling of hypertension. Hypertension. 18(5):III115-III121.

34. Kifor, I., and V. J. Dzau. 1987. Endothelial renin-angiotensin pathway:evidence for intracellular synthesis and secretion of angiotensins. Circ. Res. 60:422428.

35. Dzau, V. J., and G. H Gibbons. 1993. Vascular remodeling: mechanisms and implications. J. Cardiovasc. Pharm. 21:S1-S5.

36. Rakugi, H., H. J. Jacob, J. E. Krieger, J. R. Ingelfinger, and R. E. Pratt. 1993. Vascular injury induces angiotensinogen gene expression in the media and neointima. Circulation 87:283-290.

37. Nagata, M., K. Schärer, and W. Kriz. 1992. Glomerular damage after uninephrectomy in young rats. I. Hypertrophy and distortion of capillary architecture. Kidney Int. 42:136-147.

38. Lee, L. K., A. S. Pollock, and D. H. Lovett. 1993. The asymmetric origins of the mature glomerular basement membrane. J. Cell. Physiol. 157(1):169177.

39. Miller, P. L., and T. W. Meyer. 1990. Methods in laboratory investigation effects of tissue preparation on glomerular volume and capillary structure in the rat. Lab. Invest. 63(6):862-866.

40. Schwartz, M. M., and A. K. Bidani. 1993. Comparison of glomerular injury in juvenile versus mature rats in a remnant kidney model. J. Lab. Clin. Med. 121(2):348-55.

41. Chansel, D., S. Czekalski, P. Pham, and R. Ardaillou. 1992. Characterization of angiotensin II receptor subtypes in human glomeruli and mesangial cells. Am. J. Physiol. 31:F432-F441.

42. Sanes, J. R., E. Engvall, R. Butkowski, and D. D. Hunter. 1990. Molecular heterogeneity of basal laminae: isoforms of laminin and collagen IV at the neuromuscular junction and elsewhere. J. Cell Biol. 111:1685-1699.

43. Vanden-Heuvel, G. B., and D. R. Abrahamson. 1993. Quantitation and localization of laminin A, B1, and B2 chain RNA transcripts in developing kidney. Am. J. Physiol. 265:F293-F299.

44. Laurie, G. W., S. Horikoshi, P. D. Killen, B. Segui-Real, and Y. Yamada. 1989. In situ hybridization reveals temporal and spatial changes in cellular expression of mRNA for a laminin receptor, laminin, and basement membrane (type IV) collagen in the developing kidney. J. Cell Biol. 109:1351-1362.

45. Abrahamson, D. R., and P. L. St. John. 1993. Laminin distribution in developing glomerular basement membranes. Kidney Int. 43:73-78.

46. Abrahamson, D. R. 1985. Origin of the glomerular basement membrane visualized after in vivo labeling of laminin in newborn rat kidneys. J. Cell Biol. 100:1988-2000.

47. Sariola, H., R. Timpl, K. von der Mark, R. Mayne, J. M. Fitch, T. F. Linsenmayer, and P. Ekblom. 1984. Dual origin of glomerular basement membrane. Dev. Biol. 101:86-96.

48. Floege, J., C. E. Alpers, M. W. Burns, P. Pritzl, K. Gordon, W. G. Couser, and R. J. Johnson. 1992. Glomerular cells, extracellular matrix accumulation, and the development of glomerulosclerosis in the remnant kidney model. Lab. Invest. 66(4):485-497.

49. Nagata, M., and W. Kriz. 1992. Glomenular damage after uninephrectomy in young rats. II. Mechanical stress on podocytes as a pathway to sclerosis. Kidney Int. 42:148-160.

50. Walpola, P. L., A. I. Gotlieb, and B. L. Langille. 1993. Monocyte adhesion and changes in endothelial cell number, morphology, and F-actin distribution elicited by low shear stress in vivo. Am. J. Pathol. 142(5):1392-1400.

51. Resnick, N., T. Collins, W. Atkinson, D. T. Bonthron, C. F. Dewey, and M. A. Gimbrone. 1993. Platelet-derived growth factor B chain promoter contain a cis-acting fluid shear-stress-responsive element. Proc. Natl. Acad. Sci. USA. 90:4591-4595.

52. Itoh, H., M. Mukoyama, R. E. Pratt, G. H. Gibbons, and V. J. Dzau. 1993. Multiple autocrine growth factors modulate vascular smooth muscle cell growth response to angiotensin II. J. Clin. Invest. 91:2268-2274.

53. Floege, J., M. W. Burns, C. E. Alpers, A. Yoshimura, P. Pritzl, K. Gordon, R. A. Seifert, D. F. Bowen-Pope, W. G. Couser, and R. J. Johnson. 1992. Glomerular cell proliferation and PDGF expression precede glomerulosclerosis in the remnant kidney model. Kidney Int. 41:297-309.

54. Ciechanowicz, A., J. Wagner, A. Wystrychowski, D. Ganten, and E. Ritz. 1993. Enalapril prevents induction of PDGF mRNA expression in the rat remnan kidney model. J. Am. Soc. Nephrol. 4(3):766a. (Abstr.).

55. Noble, N. A., S. Kagami, and W. A. Border. 1993. Angiotensin II stimulates extracellular matrix protein synthesis through activation of transforming growth factor- $\beta$ synthesis in cultured mesangial cells. J. Am. Soc. Nephrol. 4(3);661 (abstract)

56. Junaid, A., M. E. Rosenberg, and T. H. Hostetter. 1993. Interaction of angiotensin II and transforming growth factor beta in the remnant kidney. J. Am. Soc. Nephrol. 4(3):772 (abstract).

57. Schunkert, H., J. R. Ingelfinger, H. Jacob, B. Jackson, B. Bouyounes, and V. J. Dzau. 1992. Reciprocal feedback regulation of kidney angiotensinogen and renin mRNA expressions by angiotensin II. Am. J. Physiol. 26:E863-E869.

58. Gibbons, G. H., R. E. Pratt, and V. J. Dzau. 1992. Vascular Smooth muscle cell hypertrophy vs hyperplasia: autocrine transforming growth factor- $\beta$ expression determines growth response to angiotensin II. J. Clin. Invest. 90:456461.

59. Johnson, R. J., H. Iida, C. E. Alpers, M. W. Majesky, S. M. Schwartz, P. Pritzl, K. Gordon, and A. M. Gown. 1991. Expression of smooth muscle cell phenotype by rat mesangial cells in immune complex nephritis: $\alpha$-smooth muscle actin is a marker of mesangial cell proliferation. J. Clin. Invest. 87:847-858. 